\title{
Using transdisciplinarity in the university: Giving a voice to the voiceless in the grounding program at Fort Hare
}

\author{
TC GARUTSA' AND PM MAHLANGU
}

\begin{abstract}
In this article giving a voice to students in higher institutions acknowledges that there is much to be gained from entering into the students' world and respecting their versions of reality. If transdiciplinarity is to be achieved in institutions of higher education, knowledge should be presented through mutual learning and dialogue across disciplines towards a horizon of shared understanding. The student participation, transdisciplinary interface provides a critical framework and an experience of building a diverse intellectual community as a basis for curriculum renewal. This paper builds upon fieldwork conducted amongst students enrolled for the Grounding Program also known as Life Knowledge Action and staff. Unstructured interviews were used. Narrative descriptions where derived and were analysed through content analysis. The findings indicated that, the student participation-transdisciplinarity interface is elucidated through the case of the Life Knowledge Program under the Centre for Transdisciplinary Studies at the University of Fort Hare. The interface is embedded in the exchange of ideas which supercedes mono-inter- discipline, addressing cross cutting issues that create additional value. The discourse of Transdisciplinarity has been promoted through the structure of the curriculum and emphasis placed on the attainment of mutual dialogue amongst learners themselves and with lecturers.
\end{abstract}

Key Words: Student participation, Trandisciplinarity, Grounding Program, University of Fort Hare

\section{Introduction}

This paper aims to discuss the interface of giving a voice to students in the Higher Institutions of learning. In this paper, the notion of 'voice' is used to describe the views and thoughts of students from different disciplines, facilitators and the interns. The idea of student participation or role of students in curriculum development in higher education

1. Centre for Transdisciplinary Studies, Law Building. University of Fort Hare, Alice, 5700, South Africa, Email: tgarutsa@ufh.ac.za

2. Centre for Transdisciplinary Studies, University of Fort Hare, 50 Church St. East London, 5200, South Africa. Email: pmahlangu@ufh.ac.za 
systems is not a new phenomenon. It emerged prior to World War Two (Kridel, 1983). Similarly over the years, more innovative studies (Roberts, 2000; Messiou, 2003; Davie and Galloway, 1996) advocate for the importance of giving students a voice; the need to listen to what students say and how they say it. The above mentioned scholars attempted to access the views of the students themselves rather than through second hand accounts from others. Such research has found that mutual dialogue not only acknowledges the rights of learners to participate in the learning process but it also acknowledges that there is much to be gained from entering their world and respecting their versions of reality.

Shor and Freire (1987) confirm that dialogical education (which has as one of its basic tenets participatory education) transforms social relations in the classroom and further raises awareness about relations at large. Friere (1987) mentions that dialogue rejects narratives lecturing, the learners and the students embark on a collaborative learning process. In addition Oliver (2000) argues that,

\section{(I)nsider perspectives are essential to our attempts to grapple with any social phenomena} but, by themselves and in themselves, they can never be enough.

In other words, students' voices provide an additional perspective in trying to understand knowledge and changing the dominant way of learning, but they are not the only perspective that should be taken into consideration.

Equally the concept of transdisciplinarity needs to be briefly unpacked in order to see how it relates to the notion of student participation. The knowledge base of transdisciplinarity contributes best to ensuring novel ideas which are not generated in disciplinary isolation but nourish the fertile ground between disciplines, and understands synergies, complexities and multiple realities (McGregor, 2004). Transdisciplinary is undoubtedly pertinent, relevant to solving complex world problems and is built on strong research expertise and knowledge that is transverse and goes beyond monodisciplinarity (McGregor, 2011). In a nutshell participants involved in transdisciplinary learning process (students, facilitators and lectures) should be active rather than passive participants (McGregor, 2004).

Before examining the background and structure of the Life Knowledge Action (LKA) and Grounding Program under the Centre of Transdisciplinary Studies (CTS) at the University of Fort Hare, this section will briefly explain the methodology used for this study.

\section{Methodology}

This study used a qualitative research design which allowed the researcher to interpret phenomena in terms of the meanings people bring to them. In order to understand Transdisciplinarity in institutions of higher education through mutual learning and dialogue across disciplines the study made use of two kinds of data collection: interviews and documents which led to narrative descriptions. These data collection methods were ideally suited to obtaining relevant data on the realities and experiences associated with student participation and transdisciplinary that provides a critical framework for curriculum renewal. Interviews allowed the informants to express their realities, experiences and interpretations of student participation and transdisciplinarity in learning institutions. This enabled the researcher to gain thick descriptions and multiple interpretations rather than the imposition of one dominant interpretation (Mouton \& Marais 1990:175). Documents like reports course outlines assisted the researcher in gaining a broader understanding of how the grounding 
program elicits transdisciplinarity and student participation in institutions of Higher Learning.

\section{Sampling procedure}

The research study utilized a non-probability sampling method: purposive sampling. The power of purposive sampling lies in selecting information-rich cases for in-depth analysis related to the central issues being studied (De Vos, 2005). Purposive sampling targets a particular group of people so the researcher purposefully selected the research participants. The sample frame included representatives of students enrolled for the grounding program and representatives from interns, facilitators and academic coordinators to ensure adequate representation from all sectors. Participants were selected on this criterion: willing participation, informed consent, seniority for facilitators and interns.

\section{Data analysis}

The researcher used content analysis to bring order, structure and meaning to the mass of data collected. According to De Vos (2005), qualitative data analysis transforms data into findings. This involved reducing the volume of raw information, sifting for significant patterns and constructing a framework for communicating the essence of what the data reveals. Content analysis allowed the researcher to discuss the common themes from the thick descriptions of how participants have experienced transdisciplinarity and participation in the process of curriculum renewal. The common themes derived from the interviews and documents included: The background of the program, the significance of transdisciplinarity, the structure of Life Knowledge Action and student involvement and participation in the grounding program.

The following section will elaborate on the structure and the aims of the Life Knowledge Action (LKA) and Grounding Program under the Centre of Transdisciplinary Studies (CTS) at the University of Fort Hare, Eastern Cape, South Africa.

\section{The Background: Structure and aims}

The university of Fort Hare launched a program called the Grounding Program (GP) or Life Knowledge Action (LKA) under the Center for Transdisciplinary Studies in 2009, where first year students from diverse disciplines were provided a platform for mutual dialogue between the lecturers and the learners to produce new forms of democratic knowledge. LKA/GP IS a flexible course which is built in an interdisciplinary nature. The LKA/GP is a semester course at National Qualifications Framework level 7 carrying 16 credits and the credits contribute to the overall credits of an undergraduate degree. In a pilot study 336 students participated and 259 were formally registered. Two hundred and twenty two of the registered students passed, resulting in a pass rate of $85.7 \%$. The team which is comprised of the academic coordinators and interns received feedback reports from the 1700 questionnaires distributed (Keet and Porteus, 2010). Most students indicated that LKA's value is tangible and it's purpose fits the current educational situation where there is need for more critical thinkers who engage with material and are more versatile with issues outside their areas of 
specialty in education. Ninety seven percent of the students indicated that they like the program and what it offers whilst 3\% cited lack of time as the major reason for their dislike (Keet and Porteus, 2010). Some students cited the problem of the relevance of LKA/GP for their studies, despite the fact that there are six Umthamos (central themes) which are relevant to all faculties and students in the higher education system. The program was designed in such a way that it encompasses six thematic areas or content from all faculties which include:

1. Introduction to Life, Knowledge Action,

2. Collective Futures: Becoming a Proud Fort-harian,

3. Democracy Diversity and Identity,

4. Science, Technology, the Environment and Society,

5. Poverty Inequality and Development,

6. Living, loving and learning.

These all had potentially important implications for evolving new ways of learning. In particular, they pointed to ways in which the traditional education systems could be challenged to be more alert in identifying the transdisciplinary ways of solving issues affecting society. The program provides students with a critical framework beyond their designated area of study, and provides an experience of building a diverse, caring and intellectual community with a theatre for diverse and humanising pedagogies, as a basis for both curriculum renewal and support in the University. One respondent who has been enrolled for this course mentioned:

The members from my group belonged to different faculties and department, I am from social work, other members are from the management and commerce, arts, education as well as psychology amongst other departments. Working with other students from other faculties helped me because some issues that I was not familiar with were explained by other members and by doing so $i$ gained in-depth understanding. In-depth interview No. 3, June 2012

The University of Fort Hare has continued with cultivating a transdisciplinary approach which is associated to pragmatic or solution oriented research. The following section will elaborate the notion and significance of transdisciplinarity.

\section{The significance of transdisciplinarity}

The question of what constitutes transdisciplinarity is of great importance in an era where there are dilemmas in trying to define the theme and assessing its significance beyond disciplines. Pohl (2010) acknowledges that this concept has been contested, although there are similarities in the typology of the subject. One of the features, which have been popular, is that the concept of transdisciplinarity should address socially relevant issues and transcend and integrate disciplinary paradigms (Rosenfield, 1992; Janstch, 1970 and Mittelstrab, 1993). How can one attain a position that transcends and integrate disciplines? If we define transdisciplinarity as constituting the above-mentioned characteristics, then do we incorporate the idea that the subject also constitutes the notion of participatory research i.e. acknowledgement of different opinions including non academic actors and civil society as alluded to by Kotter (1999), Scholz (2002), Lawrence (2004) and Mojbork (2010)? 
Consequently transdisciplinarity is often recognised as solution oriented to understanding systems. The relevance of participation in transdisciplinarity becomes more imperative when knowledge of all disciplines is taken into cognisance. This implies intercommunicative action and continuous collaboration between disciplines and the community. Shor and Freire (1987) assert that experience at university can work to amputate learners from the concrete reality. The concepts abstracted in the intellectual training are far from the concreteness of society. Therefore in this essence, transdisciplinarity strives to inculcate learners with concrete reality of society. In order for transdisciplinarity to completely surface there is need to give voice to the previously marginalised groups in the education system and one way to realise it is through student participation. Transdisciplinarity does not negate the value of disciplines; instead it embraces the different ways of reality as a practice of research by both academic and non academic actors (McGregor, 2011).

Data has indicated that the course has managed to achieve a sense of transdisciplinarity and mutual dialogue in the process of learning. A few informants mentioned that:

The course structure cuts across disciplines, umzi groups aim to achieve this as basic support groups. The Ikhaya sessions allow students to exchange views across different disciplines. Furthermore the course content aims to achieve this since it cuts across different disciplines. In-depth interview No. 7, June 2012

LKA/GP has managed to achieve transdisciplinarity because students who are registered for the course come from different disciplines but they share common world problems that they have to solve collectively. In-depth interview No. 2, June 2012

In the process of listening and considering student voices there is a sense of belonging in both the facilitators and students in the learning process. In-depth interview No. 3, June 2012

\section{The structure of Life Knowledge Action}

The structure of the course is different, since the way lectures conducted is different. The learning community is divided into three different levels which include umzi (a Xhosa name for home), ikhaya (a Xhosa word meaning an extended home), and village. There is a rich use of isiXhosa and of cultural connectivity in the naming and functioning of groups in the program which is useful in the inclusion of indigenous dialect in the curricula.

In LKA/GP the imizi (plural form of umzi) are structured in such a way that they are comprised of six students from various disciplines factors such as nationality, race and gender are considered in building up of the umzi. These imizi are small learning communities with the two-fold purpose of helping students both to establish sound learning practices and to engage in socially important questions. One informant mentioned that:

In my umzi we were from different departments, I am studying agriculture but other members belonged to business administration, education, computer science and psychology so it was easier for me to understand some issues from other disciplines. Indepth interview No. 5, June 2012

Students from diverse academic disciplines are placed in the imizi which are student-led, that meet together to watch film clips and discuss readings (Keet, 2011). The aim of the umzi is to provide a supporting framework; self disciplined student run group taking into cognisance the idea of the members stemming from different faculties with different experiences. The following participants had this to say: 
The imizi sessions gave me confidence to speak because I was shy to speak in public. As I started to share my ideas with other members, I became more confident and in the process I learnt from others.

Furthermore, another participant mentions that

The imizi sessions promoted my participation as a student due to a small number of people or members I was not shy, each member was also given time to share what they had research on and their opinion concerning the subject matter in discussion. In-depth interview No. 4, June 2012

Group work has long been accepted as an effective learning strategy because it provides opportunities for students to negotiate meaning and manipulate ideas with others and reflect upon their learning (Fraser and Deane, 1997) Students receive participation points for taking part in the umzi.

The second level is an ikhaya. In the LKA/GP it consists of 30 students (5 imizi) which meet once in every two weeks to discuss and debate the theme during the cycle. Since LKA is a student driven course two abakwezeli (student facilitators) facilitate the discussions and are involved in the administration of registers, assignments and other rituals such as movies and imizis when it's necessary. Students are required to complete written assignments that include a research component, keep a reflective journal and complete some kind of creative project related to what they have learned.

Next level is the village which is a collection of extended families or amakhaya (more than one ikhaya). The village brings the theme/umthamo to a close. A lecturer prepares a lecture that responds to student questions that have arisen in their discussions. The ekhayas engage with the material and issues raised in the ikhaya sessions. The cycle itself allow for the interconnectedness of the rhythms and the rituals which advocate for a learning environment which encourages student participation at all levels.

LKA/GP emerged in an era where it is of importance to create African scholars who can critically engage with issues affecting the society. The importance of listening to the marginalised voices is emphasised by many authors (Rose and Shevlin, 2004; French and Swain, 2000 and Oliver, 2000) who draw attention to the multiplicity of meanings available in relation to insider perspectives, and to the issue of accessing 'insiders' perspectives and interpreting these. Furthermore, LKA/GP is based on the assumption that knowledge is socially constructed through interaction with others (Vygotsky, 1968 and Wertsch, Minick \& Arns, 1984). Freire (1970) mentions that:

There is no learning or humanization without the act of mutual dialogue. Yet for dialogue to be transformative it needs to be carried out in relations of love, mutual respect, and trust. If the capacity to dialogue offers an alternative to the "banking concept" of education, it does so because it no longer reduces the oppressed human being to the status of a thing or object.

The act of mutual dialogue raises relations at large and thus contributes humanising pedagogy anchored in love, mutual respect, trust and support. The next section will discuss briefly student participation in the Grounding program. Figure 1 is a diagram of how Student Participation is conceptualised in the LKA/GP program. 


\section{Student involvement and Participation in the LKA/GP}

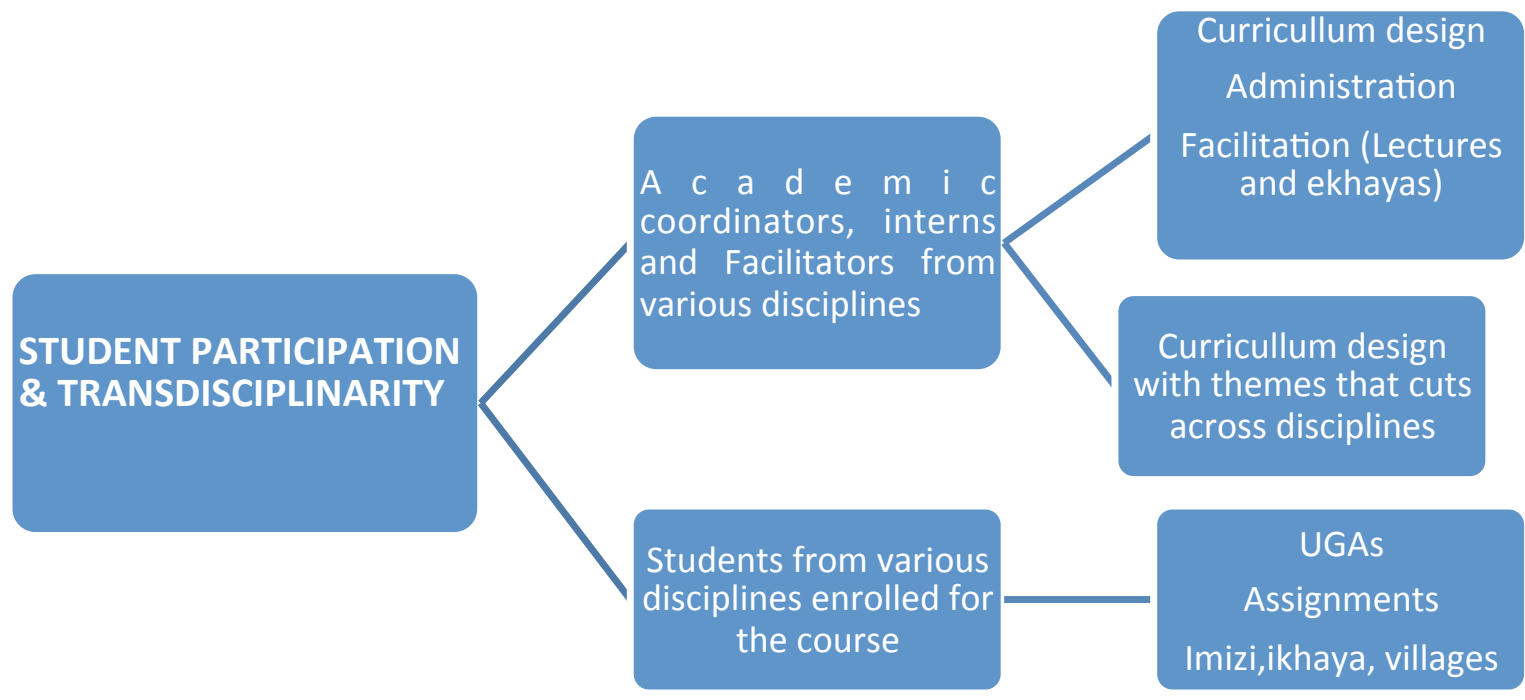

\section{Figure 1: Student Participation and transdisciplinarity in the Centre for Transdisciplinary Studies Department University of Fort Hare (Garutsa, 2012)}

Student participation makes it possible to encourage students to critically think and reflect on issues raised in that particular session (umzi, movies, ikhaya and village). Grioux (2006) affirms that:

Democratic education would seek to develop a process of learning that assist not only public forms of participation but also enable students to produce new forms of democratic knowledge.

The main purpose of Student Participation is to foster development of critical engagement and presentation skills. Student participation also encourages social interaction and sharing of ideas from different perspectives. One participant revealed that:

As students from different faculties we could approach one concept differently. This enabled me to develop a multi-dimensional perspective on issues so in a sense participation is very crucial in higher institutions of learning rather than adopting the transfer teaching methodology. In-depth interview No. 3, June 2012

The way the course is structured allows intricacy beyond disciplines through intercommunicative action and continuous collaboration of those involved in the learning process. Shor and Freire (1987) support the fact that when small groups are involved in dialogues, they reflect together on what they know and what they don't know and act critically to transform reality. The individual aspect is not enough to explain the process of knowing in the dialogue, it seals the relationship between those who know and those who try to know. In other words the quest of knowledge in a dialogue negates individualism. Shor and Freire (1987) further mention that when participating in a dialogue seals together the act of knowing and re-knowing i.e. instead of transferring the knowledge statistical as an educator the act demands a dynamic approximation towards the object. Shor and Freire (1987) notion of dialogues is paramount in the program at all level were active participation is required to achieve and foster student development through critical thinking and evaluation. 
The team i.e. academic coordinators, interns, facilitators and students enrolled for the course are actively involved to ensure the promotion of student participation and transdsciplinarity. One of the participants had this to say:

Lecturers and interns promote student participation and transdisciplinarity through facilitating the content, the readings provided cut across the areas of study allowing students provide their viewpoints to have input. In-depth interview No. 5, June 2012

Giving students a voice, or ownership of their own learning environment, leads to meaningful student involvement thereby producing critical African Scholars. In the LKA/GP this is realised through involvement of students as development partners, planners, administrators working with and not for the University as either academic coordinators, facilitators, interns and students enrolled in the course.

Facilitators plan for their own sessions encouraging them to be creative; they have a mandate to promote student engagement and transdisciplinarity in the ikhaya and village sessions. This can be substantiated with what an respondent reveals:

Ikhaya sessions provide a platform for students to participate, create dialogue and debate guided by the facilitators who give direction, encourages participation pertaining the particular umthamo. In-depth interview No. 4, June 2012

Students enrolled in the program can also be regarded as planners especially since they are responsible and accountable for their imizi. They have self-led imizi where they meet and plan; they are given an opportunity to be insightful of their needs as an umzi and are very candid about their opinions and thoughts. One respondent mentioned that:

I was able to make my own view points in discussions since there was usually enough to contribute and every member was allowed to disagree with another. In-depth interview No. 2, June 2012

and another respondent mentioned that:

When I found out that my points or my thinking was accepted by other umzi members, I became eager to share with the whole Ikhaya. In-depth interview No. 7, June 2012

Realizing such commitment and accountability fosters meaningful student involvement.

The LKA/GP actively engages students in facilitation and lecturing during the ekbaya and the village sessions. Facilitators and interns are also given the opportunity to be creative and conduct lectures in ways that aim to promote the main objectives of the program. Some have been able to create documentaries, video clips which enhance visual learning and some create PowerPoint presentations for the respective imithamos in the Curriculum. Fletcher (2008) describes that innate interests in technology enables students to contextualise technology and become literate in areas they are interested in. The program benefits everyone involved since students working as facilitators, interns gain tremendous experience and expertise since students as professional development partners are more grounded they live the teaching and teach (Martin Kneip, 2007).

The team works with and not for the University. Through administration, involvement in curriculum design, lecturing, facilitation, self-led imizi's students advocate for finding a voice, educational improvement and leading new approaches to learning and teaching in the architecture of involvement to make a difference (Corbert and Wilson, 1995). Through a 
series of guided critical reflections of the sessions, rhythms and rituals an understanding of how to improve student participation is and can be recognized. One participant reveals that:

Student participation is when students have a platform to be heard, being heard and
finally being able to impact on discussions and decisions. There is need to listen what
students say and how they say it because the learning environment needs to facilitate the
process of learning and students have first hand knowledge of this process (what works
and what is beneficial and what needs to be addressed to improve the learning process).
In-depth interview No. 4, June 2012

The imizi fosters student participation through developing group and team skills. However assessing student participation may be hard given factors like class size and group dynamics. Participation may be hard to assess objectively unless skills are laid out clearly meaning the criteria of assessment should be uniform across groups. The facilitators' assessment in the program is uniform. The facilitators and the intern team undergo training presented by qualified Facilitators from the Teaching and Learning Centre at the University (TLC and LKA training) in order to lay out clearly the assessment criteria and procedures. Assessment of performance is done on clearly defined tasks (Attendance and assignments) referred to as participation points and not on vague impressions of the quantity or quality of a student's contribution to class discussion. The assessment criterion is specified clearly i.e. in the sessions and the performance of students. For example when students attend a session they are awarded points or marks accordingly and when they participate in group assignments they are also awarded marks or participation points consequently.

Assessing student participation is paramount in educational values such as growth in critical thinking, active learning and thinking outsides' ones' discipline. Research reveals that students with a high-grade orientation value only those portions of a course that is visibly graded (Marrano et al, 1988; Janzow and Eison, 1990). When students see that their participation is being graded regularly and consistently, they adjust their study habits accordingly to be prepared for active participation.

This paper will look into three types of student participation that have been used in LKA/GP and how it has fostered transdisciplinarity. Facilitators may foster participation in open class discussions: this is when the facilitator poses questions with the aim of engaging with the ikhaya or village members (Welty, 1989). One informant mentions:

Some methods employed by facilitators to prompt participation in the ekhaya session include presentations whereby students discuss in small groups and give feedback. Indepth interview No. 7, June 2012

To facilitate the class discussion the facilitator may arrange chairs in a semicircle or circle so students can engage amongst themselves with the facilitator controlling the session. Another method for student participation used by the program is called collaborative learning, in which students work in imizi towards answering Umzi Group Assignments. Similarly, (Johnson and Johnson, 1991; Bruffee, 1993) also note that, differences among group solutions often lead to whole-class discussions (Villages) during the lecture session.

Furthermore another method used to improve student participation is "cold-calling" where the facilitator calls out students at random to respond to question. Factors such as introvert and extrovert students are taken into account. This may be done by giving a red card to the students who dominate the discussions i.e. who are always participating, giving tasks to 
introverts like scribing or facilitating group discussions. This ensures all students actively taking part in a session or lecture. One of the participants mentions that:

Facilitators employ different facilitation styles allowing for group discussions and
presentations to ensure that reading is taking place and probing critical questions gives
the platform for students to freely. These methods have been effective in promoting
transdisciplinarity and student participation through their interaction different
viewpoints is shared and knowledge is gained from different sources. In-depth
interview No. 4, June 2012

Another form of student participation in the grounding program entails some team members (facilitators, interns and academic coordinators) being given an opportunity to design the curriculum. Although Welty (1989) argues that if students sit on curriculum committees their statements are rarely given the same credibility as those of the faculty committee members, and go on to say there is little opportunity for faculty members and students to thoroughly discuss curriculum design and development. Never the less, curriculum development process should not bypass the involvement of students. Student participation in curriculum development can be traced back to the $13^{\text {th }}$ century (Perkins, 2006).

In order for the idea of student participation in transdisciplinarity to be realised, the exchange and cooperation of ideas or knowledge by students should be acknowledged for synergy effects, cross-cutting issues to create additional value. Secondly students' participation is to attain the representative legitimacy a move away from the teacher/lecturer dominated oriented environment towards a more empowering social model. Student participation is understood as a social process of individual and collective empowerment. In reality this idea has been construed differently in different contexts. A number of models have emerged over previous years reflecting a move towards students' involvement and participation in curriculum renewal and development (Finn, 1989: Jenkins, 1995)

Although student involvement is highly regarded, Morrow (1998) identifies some general problems with it such as defining who the stakeholders are, assumptions of homogeneity within each stakeholder (thereby overlooking the idea of power relations amongst the voices).

Menon (2005) is of the view that student participation creates an atmosphere of openness and trust in universities thus leading to a positive organisational climate. In a similar way, Mamashela (2011) notes that students are internal stakeholders or a politically significant constituency of the university therefore need to be involved in governing the university. It is helpful to view the university as an institution composed of internal stakeholders whose views need to be heard and ideas considered transforming antiquated formal hierarchies and disperse power (Morrow 1998:386-388, Olsen, 2007:32).

\section{Conclusion}

The Grounding program at the University of Fort Hare sheds light on transdisciplinary grounding, student participation and involvement, and the integrative quality of a transdisciplinary approach to learning. Student participation in Transdisciplinarity is embedded in the exchange and cooperation of ideas and knowledge. Furthermore the synergy effects supersede mono/inter- disciplinarily and consequently cross-cutting disciplines create additional value in the learning process. Students have increasingly become involved in the improvement and enhancement of their own learning experience. They are actively involved, 
contributing to the development of learning, participating in university decision making processes and representing student views from various disciplines in many ways. Thus students' insight and knowledge in transdisciplinary studies at the higher education system is significant, an increasingly hallmark of contemporary knowledge production and professional life.

\section{Bibliography}

Berkes, F. (2003). Learning as you journey: Anishinaabe perception of social-ecological environments and adaptive learning. Conservation Ecology 8(1), p. 5.

Bruffee, K. (1993). Collaborative learning: Higher education, interdependence and the authority of knowledge. Baltimore: Johns Hopkins University Press.

Corbett, D., \& Wilson, B. (1995). Make a difference with, not for, students: A plea to researchers and reformers. Educational Researcher, 24(5), pp. 12-17.

Davie, R., and Galloway, D. (1996). The voice of the child in education. In R. Davie \& D. Galloway (Eds.), Listening to children in education London: David Fulton, pp. 1-14.

Du Toit, D.R. (2004). The Spirals Model: New options for supporting professional development of implementers of outcomes based education. Department of Education, Pretoria.

Finn, J. D. (1993). School engagement and students at risk. Washington, DC: U.S. Department of Education, National Centre for Education Statistics. Available on the Internet on 22 May 2012.

Fletcher, A (2008) Giving Students Ownership of Learning: The Architecture of Ownership. Education Leadership, 66(3), pp. 23- 29.

Fraser, S. and Dean, E. (1997) Why open learning? Australian Universities Review, 1, pp. 2531.

Giroux, H.A. (2006). Academic freedom under fire: The case for critical pedagogy. College Literature 33(4): pp. 1-42.

Jacobs, L. C., and Chase, C. I., (1992). Developing and Using Tests Effectively: A Guide for Faculty. San Francisco: Jossey-Bass.

Jantsch, E. (1970). Inter-Disciplinary and Transdisciplinary University - Systems Approach to Education and Innovation, Policy Sciences, 1: pp. 403-428.

Janzow, F and Eison, J. (1990). Grades: Their influence on students and faculty. In M. D. Svinicki (Ed.), The changing face of college teaching. New directions for teaching and learning, San Francisco, CA, Jossey-Bass: pp. 93-102.

Johnson, D. W. and Johnson, R. T. (1991). Cooperative Learning: Increasing College Faculty Instructional. Armstrong Publications.

Jones, R. C. (2008). The "why" of class participation. College Teaching, 56, pp. 59-62.

Keet, A. and Porteus, K. (2010). Report of the pilot July-December 2009, Life Knowledge Action, The Grounding Program. University of Fort Hare. 
Kötter, R. Balsiger, P.W. (1999). Interdisciplinarity and Transdisciplinarity. A Constant Challenge to the Sciences, Issues in Integrative Studies, 17: pp. 87-120.

Kridel C. (1983). Student participation in general education reform: a retrospective glance at the Harvard redbook: The Journal of General Education, 35(3), pp. 154-164.

Latour, B (1987). Reassembling the Social, Oxford: Oxford University Press.

Mamashela, T.M (2011). Student involvement in university decision-making: Good reasons, a new lens. International Journal of Leadership in Education (ILJE), University of the Western Cape, Cape Town, South Africa.

Martin-Kniep, G. (2007). Communities that learn, lead and last: Building and sustaining educational expertise. San Francisco: Jossey-Bass.

Marzano, R. and others (1988). Dimensions of Thinking: A Framework for Curriculum and Instruction. Alexandria, $\mathrm{Va}$.: Association for Supervision and Curriculum Development,

McGregor S.L.T., (2011). Transdisciplinary Approaches in Higher Education. Integral Publishers.

Menon, M.E. (2005). Students' views regarding their participation in university governance: Management, 11, pp. 167-182.

Messiou, K. (2003). Conversations with children: A pathway towards understanding marginalisation and inclusive education. Manchester: University of Manchester. Unpublished $\mathrm{PhD}$ thesis.

Mittelstraß, J. (1993). Unity and Transdisciplinarity, Interdiscipl. Sci. Rev., 18(1), pp. 53-157.

Mobjörk, M (2010). Consulting versus Participatory Transdisciplinarity: A refined classification of transdisciplinary research, Futures, 42(8), pp. 866-873.

Morrow, W. (1998). Stakeholders and senates: the governance of higher education institutions in South Africa. Cambridge Journal of Education, 28, pp. 385-405.

Nadasdy,P. (1999). The Politics of TEK: Power and the integration of Knowledge. Arctic Anthropology, 36(1-2), pp. 1-18.

Oliver, M. (2000). Why do insider perspectives matter? In M. Moore (Ed.), Insider perspectives on inclusion: Raising voices, Rising issues, Sheffield: Philip Armstrong Publications, pp. 7-17.

Olsen, J.P. (2007). The institutional dynamics of the European university. In P. Maassen and J.P. Olsen (eds) University dynamics and European integration, Doordrecht: Springer, pp. 25-54.

Perkins, D. (1998). What is understanding? In M. S. Wiske (Ed.), Teaching for understanding: linking research with practice, San Francisco: Jossey-Bass, pp. 39-57.

Pohl, C. and Hirsch Hadorn, G. (2007), Principles for Designing Transdisciplinary Research. Proposed by the Swiss Academies of Arts and Sciences, Oekom Verlag, München.

Productivity, ASHE-ERIC Higher Education Report No. 4, USA: Clearing House on Higher Education. 
Lawrence, R.J. (2004). Housing and health: from interdisciplinary principles to transdisciplinary research and practice, Futures, 36, pp. 487-502.

Roberts, H. (2000). Listening to children: And hearing them. In P. Christensen \& A. James (Eds.), Research with children: Perspectives and practices, London: Routledge Falmer, pp. 225-240.

Rosenfield, P.L (1992). The Potential of Transdisciplinary Research for Sustaining and Extending Linkages between the Health and Social-Sciences, Social Science $\mathcal{E}^{\circ}$ Medicine, 35, pp. 1343-1357.

Scholz, R.W \& Tietje, O. (2002). Embedded Case Study Methods, SAGE Publications, London, 2002.

Shor, I., \& Freire, P. (1987). What is the "dialogical method" of teaching? Journal of Education, 169(3), pp. 11-31.

Vygotsky, L. (1968). Struggles for inclusive participation in Research. Cambridge: MIT Press.

Welty, W. M. (1989). "Discussion Method Teaching: How to Make it Work" Change, July/August, Vol. 21, pp. 40-49.

Wertsch, J.V., Minick, N., \& Arns, F.J. (1984). The creation of context in joint problemsolving. In B. Rogoff \& J. Lave (Eds.), Everyday cognition: Its development in social context. Cambridge: Harvard University Press. 